\title{
Analysis on the Recovery of MNEs from the Financial Crisis: A Case Study of Unilever
}

\author{
Sai Zou ${ }^{1, *}$ \\ ${ }^{1}$ University of Glasgow, Scotland, UK \\ ${ }^{*}$ Corresponding author. Email: sarahzou623@gmail.com

\begin{abstract}
This paper mainly aims to explore the potential methods for recovering from the financial crisis, and the potential strategic actions to enhance a firm's financial performance based on perspectives of corporate governance and strategic management. This paper takes Unilever as a case study analysis to identify how Unilever dealt with the 2008 financial crisis. The data for analysing the performance of Unilever is all secondary data from the annual reports. The findings of this case study show that a firm could improve the financial performance after the financial crisis through implementing corporate social responsibility, modifying the corporate structure and changing the current business strategy. For recovering from the negative influence of financial crisis, it is also important for firms to reduce agency problems by increasing the independence of boards and using stock options.
\end{abstract}

Keywords: Corporate governance, Strategic Management, Corporate social responsibility, Corporate structure, Agency costs.

\section{INTRODUCTION}

The 2008 financial crisis caused a negative economic effect on global brands' financial performance [1]. Although those detrimental effects including the decreased share price, the negative credit rating and financial distress make some firms bankrupt, there are still some firms that get away from this financial crisis and recover their performance. Based on that, the failure and collapse of those brand resulted in public and scholars focuses on the perspective of corporate governance [2]. Studies from the empirical evidence show that firms' corporate governance plays an essential role and has an important impact on the degree of how firms are impacted and recovered from the financial crisis [3]. Therefore, this paper will demonstrate the role of corporate governance in responding to the financial crisis from three perspectives which are vision, corporate social responsibility (CSR) and corporate structure, using the example of Unilever which is a British multinational consumer goods company. Firstly, the performance of Unilever by 2009 will be analysed. Subsequently, the relevant changes and actions to deal with the financial crisis will be evaluated through an empirical example.
Finally, based on those, some strategic suggestions and implications will be made.

\subsection{Performance of Unilever by 2009}

According to the financial indicators from 2004 to 2009 in figure 1, Unilever's overall performance was poor. First, from 2004 to 2009, Unilever's net profit increased, whereas the growth rate of net profit declined year by year. According to the growth of net profit, the company has the ability to increase net profit [9], and Unilever's performance of growth in net profit in 2009 turned out to be the worst which stands at $-31.01 \%$, demonstrating that Unilever's profitability is extremely low. In addition, the positive side is that the sales seem to remain stable on the surface level, but the downside is that the sales in growth is still declining, indicating that Unilever is not profitable by 2009 . Essentially, it indicates that Unilever was not profitable as before. Apart from that, operating profit is another indicator to measure the profitability of financial performance [10]. After continuous growth in operating profit from 2004 to 2008, Unilever experienced a dramatically decline in 2009 which decreased by $30.14 \%$, showing that 
Unilever's weak ability to convert sales into net profit.

Table 1. Financial indicators [4-8]

\begin{tabular}{|c|c|c|c|c|c|c|}
\hline Financial & 2004 & 2005 & 2006 & 2007 & 2008 & 2009 \\
\hline $\begin{array}{l}\text { Net profit } \\
(€ \text { million) }\end{array}$ & 2,941 & 3,975 & 5,015 & 4,136 & 5,285 & 3,646 \\
\hline $\begin{array}{l}\text { Growth in net } \\
\text { profit }\end{array}$ & & $35.16 \%$ & $26.16 \%$ & $-17.53 \%$ & $27.78 \%$ & $-31.01 \%$ \\
\hline $\begin{array}{l}\text { Sales } \\
(€ \text { million })\end{array}$ & 37,168 & 38,401 & 39,642 & 40,187 & 40,523 & 39,823 \\
\hline $\begin{array}{l}\text { Growth in } \\
\text { sales }\end{array}$ & & $3.32 \%$ & $3.23 \%$ & $1.37 \%$ & $0.84 \%$ & $-1.73 \%$ \\
\hline $\begin{array}{l}\text { Operating } \\
\text { profit } \\
(€ \text { million })\end{array}$ & 3,981 & 5,074 & 5,408 & 5,245 & 7,167 & 5,007 \\
\hline $\begin{array}{l}\text { Growth in } \\
\text { operating } \\
\text { profit }\end{array}$ & & $27.46 \%$ & $6.58 \%$ & $3.01 \%$ & $36.64 \%$ & $-30.14 \%$ \\
\hline
\end{tabular}

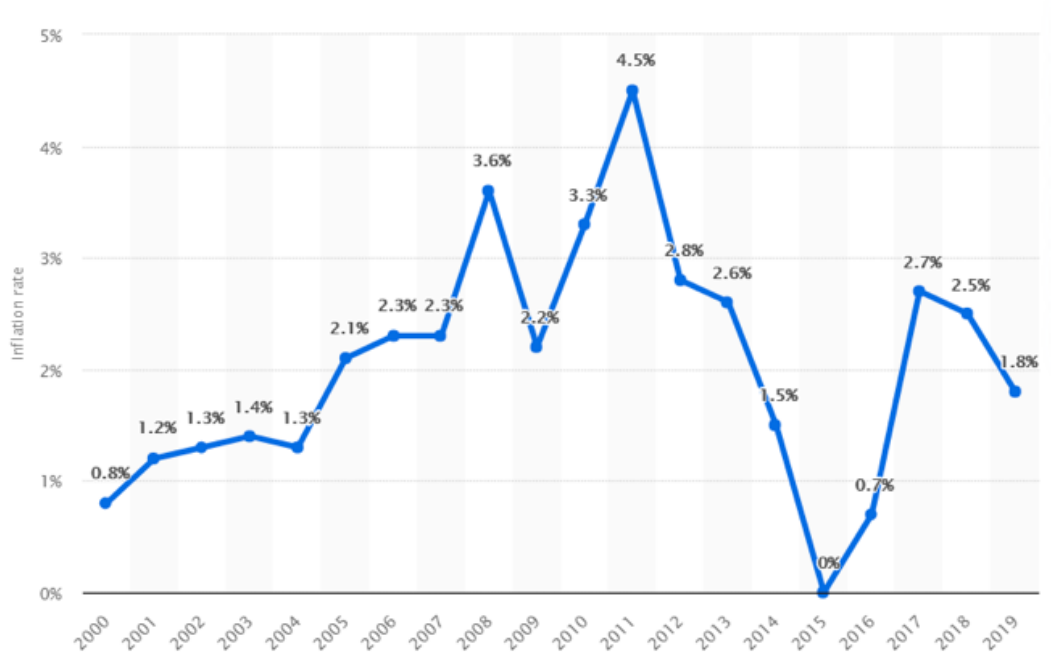

Figure 1 Consumer price index (CPI) inflation rate in the United Kingdom (UK).

Based on the fact that inflation will aggravate long-term development of the company, the growth rate in sales should offset its impact on achieving sustainable growth [12]. As shown in "Figure 1", the inflation rate of the United Kingdom which is the main operating country for Unilever, is $2.2 \%$ in
2009. Considering that the growth in sales obtained in "Table 1" is negative $1.73 \%$, the growth is much lower than the inflation loss, which illustrates that Unilever has been in long-term development under financial risks. 
Table 2. Proportion of staff cost and employee reduced [7] [13]

\begin{tabular}{|l|c|c|}
\hline Year & 2005 & 2009 \\
\hline Number of employees & 206,000 & 163,000 \\
\hline Employees turnover (\%) & \multicolumn{2}{|c|}{$20.1 \%$} \\
\hline $\begin{array}{l}\text { Employee cost (A) } \\
\text { (\$ Million) }\end{array}$ & 5,745 & 5,237 \\
\hline $\begin{array}{l}\text { Turnover (B) } \\
\text { (\$ Million) }\end{array}$ & 38,401 & 39,823 \\
\hline $\begin{array}{l}\text { Proportion of employee cost } \\
\text { (A/B) }\end{array}$ & $15.0 \%$ & $13.2 \%$ \\
\hline \begin{tabular}{l} 
Reduce in employee cost (\%) \\
\hline
\end{tabular} & \multicolumn{1}{|c|}{$1.8 \%$} \\
\hline
\end{tabular}

Based on the non-financial indicators in "Table $2 "$, the number of employees indicates a dramatically decline from 2005 to 2009. Human capital is of vital significance comprising of individuals' knowledge with capabilities together, therefore, organisational performance would be negatively affected by the employee turnover [14]. From 2005 to 2009, employee turnover standing at $20.1 \%$ in figure 3 demonstrates that it not only adversely affected Unilever's performance, but also reduced staff costs by only about $2 \%$, which shows that the cost-effectiveness of employees is not good. To be specific, the labour flexibility has a positive relationship with cost-efficiency [15], showing that Unilever's low level of labour flexibility and cost efficiency has led to its lagging performance. Overall, both financial and nonfinancial indicators illustrate that Unilever's performance was lagging by 2009 .

\subsection{Change in Vision with CSR}

Before analysing the changes to CSR, it is important to analyse the effect of change of CEO. Firstly, based on the previous performance analysis, Unilever's lagging performance by 2009 enforced the company to hire an outsider who can positively influence firm's performance [16]. Take Procter \& Gamble in 2008 as an instance, the company hired four outsiders in that year, all of whom had served as CEOs to improve the company's efficiency [17]. Moreover, Polman has competences to recognition and identify opportunities. For instance, Polman, who is good at seizing opportunities, led Nestlé
Nutrition to become the world's second largest leader in healthcare and infant nutrition separately, contributing a total of 11 billion US dollars to Nestlé's sales [18]. Furthermore, according to the complacency of Unilever insiders [19], Unilever's CSR and brand image are damaged. Based on that, Unilever needs to bring changes for its bad image of organisation through hiring the outsider, because external CEO succession is related to changes in existing administrative models [20].

In addition, Polman applied a revolutionary strategy for the change of vision. Revolutionary change is focusing on "clear strategic direction, top management changes, culture change and monitoring change" [21]. Polman transformed its vision into the sustainability of CSR, thereby enhancing the brand image and corporate reputation. Meanwhile, Unilever has incorporated the principles of sustainable development into its core competitiveness [22], which also provides opportunities to enhance its competitive advantage and raise a good reputation. Furthermore, since CSR can create a good ethical brand image [23], Unilever has successfully established a positive brand image by incorporating CSR into corporate marketing.

\subsection{Change in Corporate Structure}

To better shape the strategy formation and implementation, as well as realize the aim of sustainable development, Unilever's original structure has been improved from a transnational structure to a matrix structure [24]. 


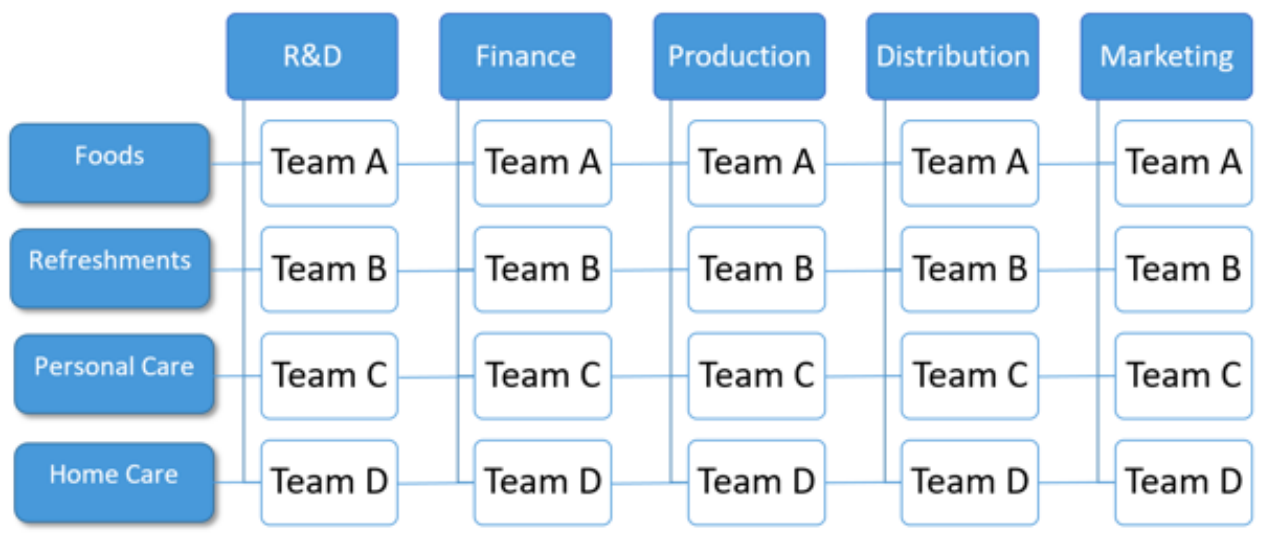

Figure 2 Matrix structure of Unilever.

Compared to the weakness of the original transnational structure which hinders resource and capability sharing, the first advantage of Unilever's matrix structure as shown in "Figure 2" is that the same goals must be set to achieve the vision of each employee. Namely, Unilever believes that cultivating employee elites is a key factor in sustainable development, therefore, the matrix structure can provide clear goals for the strategy implementation [25-26], which would make it easier for employees to follow the vision and improve employees' enthusiasm and motivation to achieve sustainable development. In addition, Unilever encourages employees to jointly create sustainable development through the matrix structure [27-28]. Accordingly, Unilever's strategic direction in sustainability would be ensured by matrix structure.

The second merit of Unilever's matrix structure is that it eliminates repetitive communication and thus promotes sustainable product development. Through the design of matrix structure, resource sharing between different units will be more efficient and effective [29]. To be more specific, the coordination between different departments would promote the combination of product development and sustainable innovation. Nevertheless, the dual command principle of the matrix structure will make employees feel confused to some extent [25]. Consequently, it is of vital importance for Unilever to established a fluent and precise communication channel, aiming to effectively guild employees for the implementation of strategy.

\subsection{Change in Business Strategy}

According to market dynamics, emerging markets have become an integral part, which will mainly affect the profits of international packaged goods companies [30-31]. To occupy more market share in emerging countries, the business-level strategy of Unilever was changed from market penetration to market development. Importantly, Unilever successfully expanded its customer base in the emerging markets which contains China and India [32]. Among them, more than half of Unilever's revenue in 2014 (5.7 billion euros) came from emerging markets. This is a good indication that the change in business-level strategy will help Unilever enhance the profitability, and it will also help the company recover from the 2008 financial crisis by entering to emerging markets. Overall, strategic changes not only freed Unilever from its predicament, but also improved its economic growth at the same time.

As a result, change in corporate governance could be an effective way to manage the financial crisis. Therefore, according to the example of Unilever, CSR corporate structure and business strategy might be essential in dealing with the lagging performance caused by the external environment.

\section{SUGGESTION}

According to "Figure 3", the business canvas model shows Unilever's nine elements, including current key partners, key activities, key resources, value propositions, channels, customer relationships, customer segments, cost structure and revenues streams. The strategic suggestion for Unilever will be made from the perspective of cost structure which is associated with corporate governance. To improve the costs structure, one of the key element is to reduce the unnecessary costs caused by agency problem. 


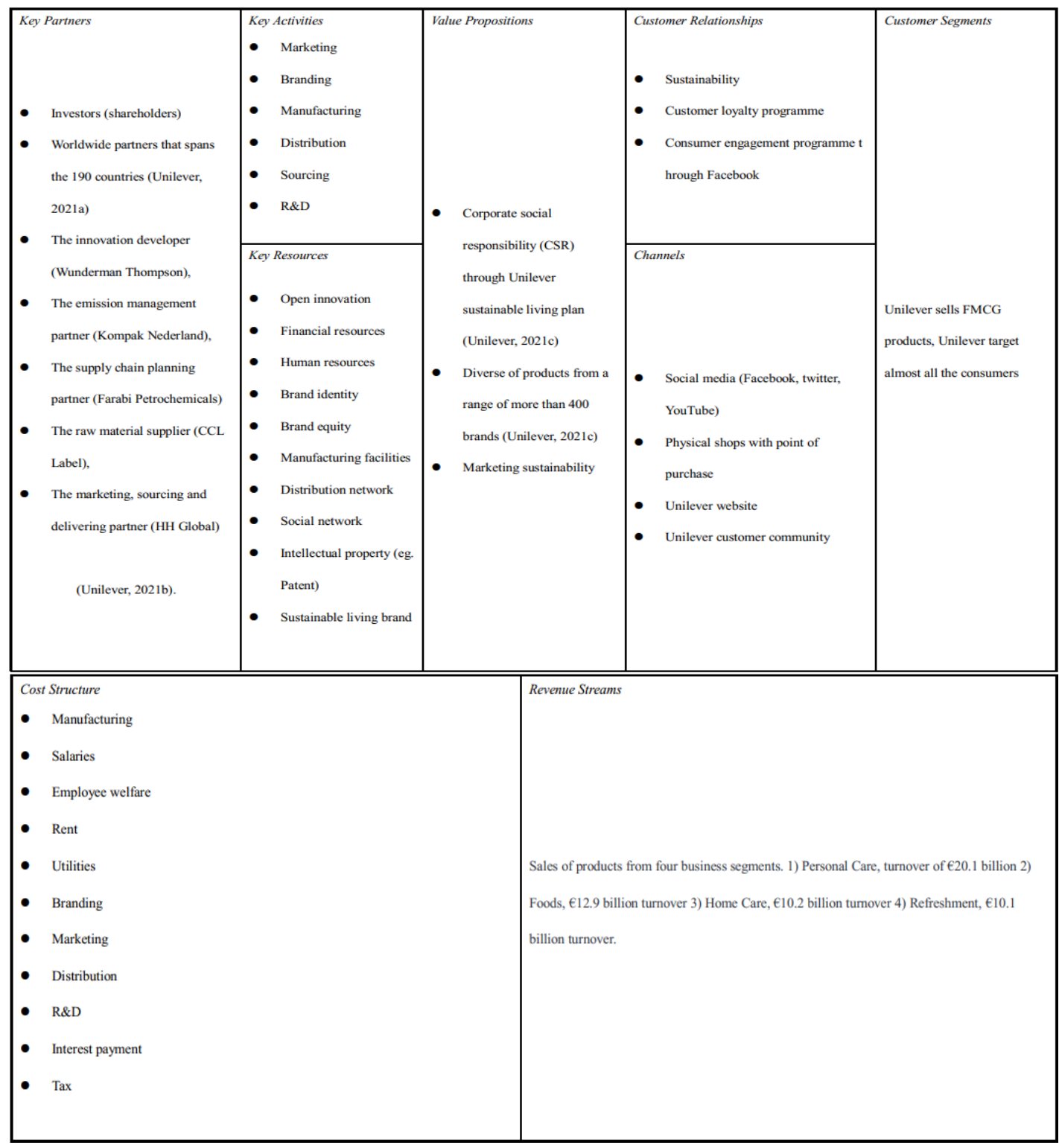

Figure 3 The business canvas model of Unilever.

Most importantly, it is important to link the managers' interest to shareholders' interest for a firm. Due to the separation of ownership, the shareholders cannot fully manage the managers' behaviour where those managers sacrificed the interests of shareholders at the expense of their best interests, thus resulting in agency problem between shareholders and managers [33]. Based on those agency problems, agency costs and monitoring will emerge which could cause a huge amount of costs in managing them [34]. The financial health and financial performance of a firm is linked with an independent board and the degree of agency problem [35-36].
As for board of director, a series of proposals were generated by the global financial crisis in order to eliminate the duality of CEOs and achieve an independent board of directors [37], because the high level of CEO duality increases the managerial power but weaken board oversight so that the board of directors should be independent of the management team to reduce agency costs [38]. Additionally, according the evidence that independence boards will be more likely to produce a healthier financial performance in long-term [39]. Therefore, for Unilever, the amount of nonexecutive directors needs to be increased to strengthen the monitoring process without adding monitoring costs. Secondly, to avoid agency costs, 
Unilever can give the stock option for the managers which aims to link their interest with the firm's shareholder. The manager will gain a number of shares of Unilever at a discount from the option, so their personal gains are associated with the firm's performance. Stock options are as a key mechanism to manage agency problems and patricianly tie wealth of CEO to the wealth of shareholders [40]. Once the managers behave as the interest of shareholders, the financial performance can be improved. In total, Unilever could consider to minimise the agency costs during the period of financial crisis, which could help the firm to suffer less from the negative shocks.

\section{CONCLUSION}

In summary, based on the analysis above, the implications from Unilever could be seen that the effective way of recovering from the financial crisis and improving the financial performance could be focusing on CSR, modifying the corporate structure and changing business strategy. Additionally, during the financial crisis, it forces firms to pay attention to the agency problem emerging from the inside. The strategic recommendation for that issue could be increasing the independence of the board of directors and applying stock options to align the interest of managers with the interest of shareholders.

\section{AUTHORS' CONTRIBUTIONS} Zou.

This paper is independently completed by Sai

\section{ACKNOWLEDGMENTS}

Above all, it is a treasure opportunity for me to express my gratitude to Professor Matthew Grimes for providing me with a constructive criticism as well as a continuous insightful guidance. I would also like to thank my parents, sisters and friends for their contribution and support to my motivation throughout my study process.

\section{REFERENCES}

[1] Dufrénot, G., \& Keddad, B. (2014). Spillover effects of the 2008 global financial crisis on the volatility of the Indian equity markets: Coupling or uncoupling? A study on sectorbased data. International Review of Financial Analysis, 33, 17-32.
[2] Erkens, D. H., Hung, M., \& Matos, P. (2012). Corporate governance in the 2007-2008 financial crisis: Evidence from financial institutions worldwide. Journal of corporate finance, 18(2), 389-411.

[3] Brunnermeier, M. K. (2009). Deciphering the liquidity and credit crunch 2007-2008. Journal of Economic perspectives, 23(1), 77-100.

[4] Unilever (2005). Annual Report \& Accounts 2004: Full version [Online]. Available from: https://www.unilever.com/Images/2004annual-review----english_tcm 244 424084_1_en.pdf [Accessed: 06/03/2021].

[5] Unilever (2006). Annual Report \& Accounts 2005: Full version [Online]. Available from: https://www.unilever.com/Images/ir-2005annual-report-english-amended_tcm244421583_en.pdf [Accessed: 06/03/2021].

[6] Unilever (2007). Annual Report \& Accounts 2006: Full version [Online]. Available from: https://www.unilever.com/Images/ir-06annual-report-en_tcm244-421560_en.pdf [Accessed: 06/03/2021].

[7] Unilever (2008). Annual Report \& Accounts 2007: Full version [Online]. Available from: https://www.unilever.com/Images/ir-unilever07-annual-report-en_tcm244-421750_en.pdf [Accessed: 06/03/2021].

[8] Unilever (2009). Annual Report \& Accounts 2008: Full version [Online]. Available from: https://www.unilever.com/Images/ir-ar08annual-report_tcm244-421619_en.pdf [Accessed: 06/03/2021].

[9] Dita, A. H., \& Murtaqi, I. (2014). The Effect of Net Profit Margin, Price to Book Value and Debt to Equity Ratio to Stock Return in the Indonesian Consumer Goods Industry. Journal of Business and Management, 3(3), pp. 305315.

[10] Farris, P. W., Bendle, N., Pfeifer, P., \& Reibstein, D. (2010). Marketing Metrics: The Definitive Guide to Measuring Marketing Performance. Upper Saddle River, New Jersey: Pearson Education, Inc.

[11] Statista (2020). Percentage change year-onyear of the consumer price index (CPI) in the United Kingdom (UK) from 2000 to 2019. [Online]. Available from: https://www.statista.com/statistics/306648/infl 
ation-rate-consumer-price-index-cpi-unitedkingdom-uk/ [Accessed: 06/03/2021].

[12] Higgins, R. C. (1981). Sustainable growth under inflation. Financial Management, 10(4). pp. 36-40.

[13] Unilever (2018). Charts 2009 - 2018 [Online]. Available from: https://www.unilever.com/Images/unilevercharts-2018_tcm244-534891_en.pdf [Accessed: 06/03/2021].

[14] Mohr, D. C., Young, G. J., \& Burgess, Jr, J. F. (2012). Employee turnover and operational performance: The moderating effect of group - oriented organisational culture. Human Resource Management Journal, 22(2), pp. 216-233.

[15] Karuppan, C. M., \& Ganster, D. C. (2004). The labor-machine dyad and its influence on mix flexibility. Journal of Operations Management, 22(6), pp. 533-556.

[16] Georgakakis, D., \& Ruigrok, W. (2017). CEO succession origin and firm performance: A multilevel study. Journal of Management Studies, 54(1), pp. 58-87.

[17] Fahlenbrach, R., Low, A., \& Stulz, R. M. (2010). Why do firms appoint CEOs as outside directors?. Journal of Financial Economics, 97(1), pp. 12-32.

[18] Henderson, R., \& Johnson, R. (2011). Nestlé SA: nutrition, health and wellness strategy. Harvard Business Review.

[19] Ogrizek, M. (2002). The effect of corporate social responsibility on the branding of financial services. Journal of Financial Services Marketing, 6(3), pp. 215-228.

[20] Dalton, D. R., \& Kesner, I. F. (1985). Organizational performance as an antecedent of inside/outside chief executive succession: An empirical assessment. Academy of management Journal, 28(4), pp. 749-762.

[21] Whittington, R, Johnson, G, Scholes, K, Angwin, D \& Regener, P (2017). Exploring strategy. 11th ed. Harlow [etc.]: Pearson

[22] Jurietti, E., Mandelli, A., \& Fudurić, M. (2017). How do virtual corporate social responsibility dialogs generate value? A case study of The Unilever Sustainable Living Lab.
Corporate Social Responsibility and Environmental Management, 24(5), pp. 357367.

[23] Alwi, S. F. S., Ali, S. M., \& Nguyen, B. (2017). The importance of ethics in branding: mediating effects of ethical branding on company reputation and brand loyalty. Business Ethics Quarterly, 27(3), pp. 393-422.

[24] Maljers, F. A. (1992). Inside Unilever: The evolving transnational company. Harvard Business Review, 70(5), pp. 46-52.

[25] David, F. (2013). Strategic Management. Old Tappan: Pearson Education UK.

[26] Dentoni, D., \& Veldhuizen, M. (2012). Building capabilities for multi-stakeholder interactions at global and local levels: the case of Unilever. International Food and Agribusiness Management Review, Vol 15, pp. 95-106.

[27] Polman, P., \& Bhattacharya, C. (2016). Engaging employees to create a sustainable business. Stanford Social Innovation Review, 14(4), pp. 34-39.

[28] Harris, P \& McDonald, F, (2004). European Business And Marketing. London: SAGE.

[29] Laslo, Z., \& Goldberg, A. I. (2001). Matrix structures and performance: The search for optimal adjustment to organizational objectives. IEEE Transactions on Engineering Management, 48(2), pp. 144-156.

[30] Burgess, S. and Steenkamp, J.-B. (2013). Editorial: introduction to the special issue on marketing in emerging markets, International Journal of Research in Marketing, 30(1), pp. 1-3.

[31] Romaniuk, J., Dawes, J., \& Nenycz-Thiel, M. (2018). Modeling brand market share change in emerging markets. International Marketing Review. 35(5), pp. 785-805.

[32] Unilever (2010). Annual Report \& Accounts 2009: Full version [Online]. Available from: https://www.unilever.com/Images/ir-unileverar09_tcm244-421759_en.pdf [Accessed: 06/03/2021].

[33] Klein, B. (1983). Contracting costs and residual claims: the separation of ownership and control. The Journal of Law and Economics, 26(2), 367-374. 
[34] Jensen, M. C., \& Meckling, W. H. (1976). Theory of the firm: Managerial behavior, agency costs and ownership structure. Journal of financial economics, 3(4), 305-360.

[35] Aktas, N., Andreou, P. C., Karasamani, I., \& Philip, D. (2019). CEO duality, agency costs, and internal capital allocation efficiency. British Journal of Management, 30(2), 473493.

[36] Widiantoro, D. M. (2012). Measuring the Impact of Intangible Asset Investment Toward Company Financial Health and Company Agency Problem: Empirical Research from Indonesian Companies During World Economic Financial Crisis 2006-2011. Journal of Finance and Risk Perspectives, 1(2).

[37] Krause, R., M. Semadeni and A. A. Cannella (2014). 'CEO duality: a review and research agenda', Journal of Management, 40, pp. 256286.

[38] Fama, E. F., \& Jensen, M. C. (1983). Separation of ownership and control. The journal of law and Economics, 26(2), 301-325.

[39] Al-Gamrh, B., Al-Dhamari, R., Jalan, A., \& Jahanshahi, A. A. (2020). The impact of board independence and foreign ownership on financial and social performance of firms: evidence from the UAE Journal of Applied Accounting Research.

[40] Nyberg, A. J., Fulmer, I. S., Gerhart, B. and Carpenter, M. A. (2010). 'Agency theory revisited: CEO return and shareholder interest alignment'. Academy of Management Journal, 53, 1029-49. 